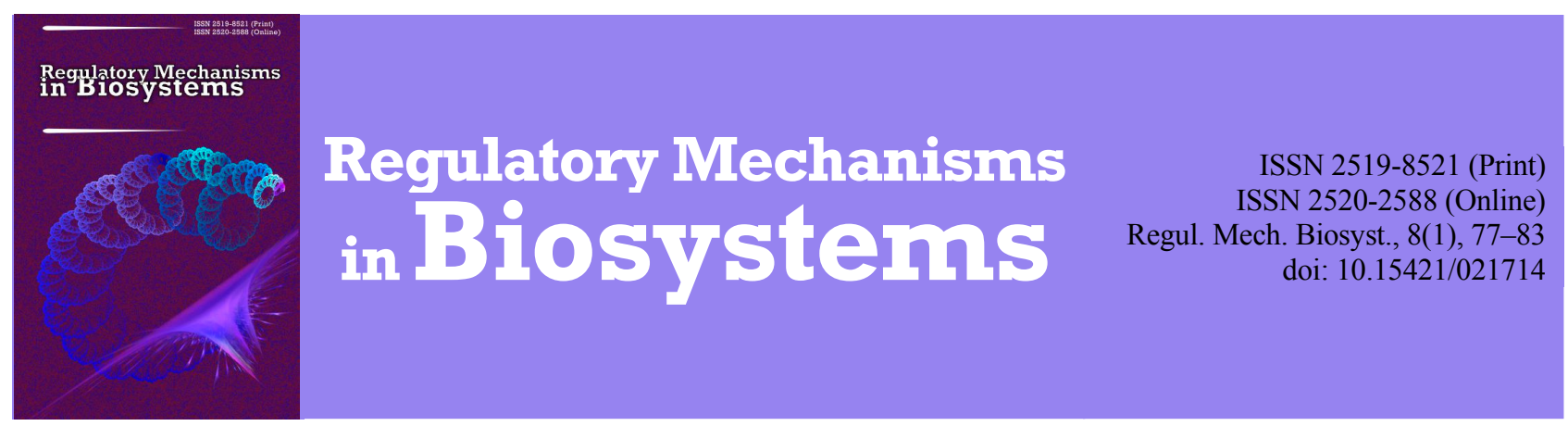

\title{
Condition of the prooxidant-antioxidant system of some strains of Basidiomycetes
}

\author{
O. V. Fedotov \\ Donetsk National Medical University, Kramatorsk, Ukraine
}

Article info

Received 06.01.2017

Received in revised form 14.02.2017

Accepted 17.02.2017

Donetsk National

Medical University

Boulevard of Mechanical

Engineers, 39,

Kramatorsk, 84331, Ukraine

Tel.: +38-068-717-87-87

E-mail: bio.graff@ukr.net

\author{
Fedotov, $\mathrm{O} . \mathrm{V}$. (2017). Condition of the prooxidant-antioxidant system of some strains of Basidiomycetes. Regulatory \\ Mechanisms in Biosystems, 8(1), 77-83. doi: 10.15421/021714
}

The article deals with the calculation and comparison indications of the condition of the prooxidant-antioxidant system (PAS) of strains of Basidiomycetes under periodic surface cultivation on a glucose-peptone medium. The research material consisted of the mycelium and culture filtrate (CF) from 57 strains, 52 of them belonging to 7 species of the order Agaricales and 5 belonging to 5 species of the order Polyporales. The intensity of the processes of lipid peroxidation was determined by a modified spectrophotometric method for contents of active products to thiobarbituric acid. Total antioxidant activity (AOA) of the mycological material was evaluated by intensity of inhibition from accumulated products of lipid peroxide oxidation (LPO) in a model reaction of oxidation by Twin- 80 oxygen of the air. From the data obtained, indicators of prooxidant activity (POA), indicators of reserve of substrate peroxidation (SPO) and the balance coefficient of the prooxidant-antioxidant system (CbPAS) were calculated. It was established that strains of Basidiomycetes are characterized by significant predominance of prooxidant activity characteristic of PAS in the culture filtrate in comparison with the mycelium indicator. The highest values of POA in the Culture Filtrate were observed on the 12-th day of cultivation for the strain P-089 genus Pleurotus and strain Gl-2 genus Ganoderma, and for the mycelium on the 9-th day of cultivation for the strains P-citr, P-089, P-er and P-082 of the genus Pleurotus. There is a direct dependence between the indicators of POA in the CF and mycelium for each strain, this dependence and level of indication do not reflect their systematic placement. We distinguished a more significant prevalence of indicators of reserve of substrates peroxidation of mycelium for most strains, than for such indicators with CF The highest value of reserve SPO of mycelium was recorded for strains P-447, P-998, P-039, P-94, P-2175, P-citr, P-er, D-140 of the genus Pleurotus and strains F-107, F-610 of the genus Flammulina. For the majority of the strains there was a clear prevalence of the values of the balance coefficients for PAS of mycelium over those of CF. Maximum values of the balance coefficient PAS of mycelium on the 9-th day were recorded for strains T-10 (F. fomentarius) and D-140, P-035, P-01, P-105 (P. ostreatus) and on the 12-th day for strains Sc-10 (S. commune), P-k1, P-14 (P. ostreatus), P-er $(P$. eryngii) i 960 (A. cylindracea). The abovementioned strains are distinguished by the with high level of AOA in the mycelium on certain days of cultivation and can be recommended as producers of antioxidants of fungal origin.

Keywords: prooxidant activity; antioxidant activity; mushrooms; surface cultivation; glucose-peptone medium

\section{Стан прооксидантно-антиоксидантної системи деяких штамів базидіомікотових грибів}

\author{
О. В. Федотов
}

Донецький національний медичний університет, Краматорськ, Україна

Робота присвячена розрахунку та порівнянню показників стану прооксидантно-антиоксидантної системи (ПАС) штамів базидіомікотових грибів за їх поверхневого періодичного культивування на глюкозо-пептонному середовищі. Матеріал дослідження міцелій та культуральний фільтрат (КФ) 57 штамів: 52 із них належать до 7 видів порядку Agaricales та 5 - до 5 видів порядку Polyроrales. Інтенсивність процесів ліпідної пероксидації визначали модифікованим спектрофотометричним методом за вмістом продуктів ПОЛ, активних до тіобарбітурової кислоти. Загальну антиоксидантну активність (АОА) мікологічного матеріалу оцінювали за інтенсивністю гальмування накопичення продуктів ПОЛ у модельній реакції окиснення Твін- 80 киснем повітря. За отриманими даними розраховували показник прооксидантної активності (ПОА), показник резерву субстратів перекисного окиснення (СПО) та коефіцієнт рівноваги прооксидантно-антиоксидантної системи (КРПАС). Для штамів базидіомікотових грибів характерне переважання активності прооксидантної складової ПАС у культуральному фільтраті порівняно з цим показником міцелію. Найвищі значення ПОА КФ відмічаються на 12-ту добу культивування штаму P-089 роду Pleurotus і штаму Gl-2 роду Ganoderma, а міцелію - на 9-ту добу культивування штамів P-citr, P-089, P-er та Р-082 роду Pleurotus. Зареєстровано пряму залежність між показниками ПОА КФ і міцелію кожного штаму, ця залежність та рівень показника не відображають ї систематичного положення. Виявлено суттєву перевагу показників резерву субстратів перекисного окиснення міцелію більшості штамів над таким показником КФ. Найвищі значення резерву СПО міцелію зафіксовані для штамів Р-447, 
P-998, P-039, P-94, P-2175, P-citr, P-er, D-140 роду Pleurotus та штамів F-107, F-610 роду Flammulina. Для переважної більшості штамів характерне переважання значень коефіцієнтів рівноваги ПАС міцелію над такими КФ. Максимальні значення коефіцієнтів рівноваги ПАС 9-добового міцелію зафіксовані для штамів Т-10 (F. fomentarius) i D-140, P-035, P-01, P-105 (P. ostreatus) та 12-добового - штамів Sc-10 (S. coттипе), Р-кл, Р-14 (P. ostreatus), Р-er (P. eryngii) i 960 (A. cylindracea). Названі штами вирізняються високим рівнем АОА міцелію на встановлену добу культивування та можуть бути рекомендовані як продуценти антиоксидантів грибного походження.

Ключові слова: прооксидантна активність; антиоксидантна активність; поверхневе культивування; глюкозо-пептонне середовище

\section{Вступ}

Прооксидантно-антиоксидантна система (ПАС) живого організму включає два взаємопротилежні процеси: генерацію активних форм кисню (АФК), що ініціюють вільнорадикальне перекисне окиснення (ВРПО) та сповільнення чи припинення процесу окиснення комплексом речовин антиоксидантного захисту (АО3) (Halliwell, 2006; Winquist, 2008; Egorova et al., 2015). Увага до зміни показників ПАС пояснюється їх вирішальним значенням у функціонуванні організму на клітинному та організменому рівнях. У численних дослідженнях, які проводяться в галузі вільнорадикальної біології, показано, що розвиток дисбалансу ПАС супроводжується порушенням функціонування систем організму (Droge, 2002; Fruehauf et al., 2007). Зміщення рівноваги ПАС зумовлює зниження його резистентності до несприятливих екзогенних і ендогенних факторів і $\epsilon$ однією із ключових ланок розвитку патогенетичних явищ (Syrchin et al., 2015; Fedotov, 2016). Окисний стрес, що супроводжується переважанням прооксидантного процесу над антиоксидантним, характеризується посиленням неконтрольованих реакцій вільнорадикального окиснення (ВРО), у тому числі перекисного окиснення ліпідів (ПОЛ) з одночасним виснаженням антиоксидантної системи (АОC) (Fruehauf et al., 2007). Кореляція окисного стресу та розвитку патогенетичних явищ можлива посиленням біосинтезу власних чи внесенням додаткових про- та антиоксидантів (Cherubini et al., 2008; Syrchin et al., 2015).

Тривале використання синтетичних лікарських препаратів, у тому числі антиоксидантів обмежене через їх потенційну токсичну дію. Це підвищує актуальність пошуку високопродуктивних природних продуцентів біологічно активних речовин (БАР) (Halliwell, 2006; Pham-Huy et al., 2008; Wasser, 2011). Одні 3 перспективних організмів-продуцентів БАР профілактично-лікувальної дії - базидіомікотові гриби (Asatiani et al., 2010; Wasser, 2010, 2011; Syrchin et al., 2015). Ці організми як у природних умовах, так i за їх штучного вирощування здатні до синтезу та накопичення повноцінного протеїну та численних БАР. Приміром, їх складні ензимні комплекси прооксидантно-антиоксидантної системи задіяні у біотрансформації складних та хімічно стійких біополімерів, що має промислове (Chang, 2001; Winquist, 2008; Kapich, 2010) та екологічне значення (Eriksson et al., 1990; Fedotov, 2007; Chayka et al., 2014). Як наслідок, інтенсивно розробляються способи культивування їстівних та лікарських видів базидіомікотових та виділення їх метаболітів (Voloshko et al., 2011; Fedotov et al., 2012; Bisko et al., 2016). Це поліцукри та ензими, поліфеноли та терпени, полікетиди та стероїди, вітаміни та вітаміноподібні речовини тощо (Wasser, 2011; Voloshko et al., 2011; Velygodska et al., 2016). Ïx терапевтична дія, у першу чергу, зумовлена антиоксидантною активністю - здатністю до поглинання (scavenging) вільних радикалів, модуляції активності ензимів шляхом хелатування металів та пригнічення процесу окиснення ліпідів (Asatiani et al., 2010; Kapich, 2011; Syrchin et al., 2015). Дослідження показали, що грибні метаболіти, у тому числі антиоксиданти, мають високий рівень біодоступності, здатні швидко метаболізуватися в організмі. Вживання грибів та інших продуктів із високою концентрацією антиоксидантів зумовлює появу у плазмі крові біоактивних метаболітів, що, у свою чергу, підвищує іiі антиоксидантну активність (Cherubini et al., 2008; Bitto et al., 2010; Syrchin et al., 2015).

Мета цього дослідження - встановити та порівняти показників прооксидантно-антиоксидантної системи у динаміці росту штамів базидіомікотових грибів за їх поверхневого періодичного культивування на глюкозо-пептонному середовищі.

\section{Матеріал і методи досліджень}

Об'єкти дослідження - 57 штамів 12 видів грибів відділу Basidiomycota (Fedotov et al., 2012). Серед них до порядку Agaricales належать штами 167, 218, 960 Agrocybe cylindracea (DC.) Gillet., штам Fh-08 Fistulina hepatica Schff. ex Fr., штами F-03, F-06, F-073, F-1, F-10, F-102, F-104, F-107, F-112, F-2, F-202, F-204, F-vv, F-610 Flammulina velutipes (Curt.: Fr.) Sing., штам P-citr Pleurotus citrinopileatus Singer., штам P-er Pleurotus eryngii (DC.: Fr.) Quél., штами D-140, Hk-35, P-004, P-01, P-035, P-039, P-081, P-082, P-083, P-087, P-088, P-089, P-105, P-107, Р-12к, Р-191, Р-192, Р-203, Р-206, Р-208, Р-209, P-210, P-6v, Р-кл, Р-14, Р-4к, Р-91, Р-94, Р-998, Р-447, Р-2175 Pleurotus ostreatus (Jacq.: Fr.) P. Kumm. та штам Sc-10 Schizophyllum commипе Fr.: Fr.. До порядку Polyporales належать штам Dq-08 Daedalea quercina Fr., штам T-10 Fomes fomentarius (L. ex Fr.) Gill., штам Gl-2 Ganoderma lucidum (Curt.: Fr.) P. Karst., штам Il-4k Irpex lacteus Fr. та штам Ls-08 Laetiporus sulphureus (Bull.) Murrill. Систематичне положення видів досліджуваних штамів 3'ясоване згідно із сучасними літературними джерелами (Kirk, 2008).

Із метою встановлення показників стану прооксидантноантиоксидантної системи дослідні штами культивували періодично поверхнево за $27,5 \pm 0,02{ }^{\circ} \mathrm{C}$ протягом 12 діб у колбах Ерленмеєра ємністю 250 мл, що містили 50 мл живильного середовища. Використовували стандартне глюкозо-пептонне середовище (ГПС, $\mathrm{pH} 6,5 \pm 0,2)$ : глюкоза - 10,0 г/дм ${ }^{3}$, пептон 3,0 г/дм ${ }^{3}, \mathrm{KH}_{2} \mathrm{PO}_{4}-0,6 г /$ дм$^{3}, \mathrm{~K}_{2} \mathrm{HPO}_{4}-0,4$ г/дм ${ }^{3}, \mathrm{MgSO}_{4} \cdot$ $7 \mathrm{H}_{2} \mathrm{O}-0,5$ г/дм ${ }^{3}, \mathrm{CaCl}_{2}-0,05 \mathrm{\Gamma} / \mathrm{дм}^{3}, \mathrm{ZnSO}_{4} \cdot 7 \mathrm{H}_{2} \mathrm{O}-0,001$ г/дм ${ }^{3}$. Інокулюмом $\left(0,5 \pm 0,01 \Gamma^{2} /\right.$ дм$\left.^{3}\right)$ слугували 10 -добові міцеліальні культури штамів на сусло-агарі (СА). Режим ферментації зумовлений економічною та технологічною недоцільністю довгострокового культивування та тривалістю фази експоненціального росту штамів (Wasser, 2011; Fedotov, 2012).

Досліджували міцелій і культуральний фільтрат (КФ), які готували таким чином. Після закінчення терміну культивування штамів міцелій відділяли від культуральної рідини за температури $5 \pm 1{ }^{\circ} \mathrm{C}$ шляхом фільтрування. Отриманий міцелій промивали дистильованою водою, підсушували на фільтрувальному папері та гомогенізували шляхом розтирання в охолодженій до $1 \pm 0,5^{\circ} \mathrm{C}$ фарфоровій ступці. Міцеліальний гомогенат (МГ) використовували для приготування водної витяжки та разом із КФ - для визначення показників ПАС. Рештки міцелію переносили у відкалібровані бюкси, зважували та висушували за $+104 \pm 2{ }^{\circ} \mathrm{C}$ до постійної маси. Далі розраховували вологість і абсолютно суху біомасу (АСБ) міцелію (Dudka et al., 2003; Voloshko et al., 2011; Chayka et al., 2014).

Із метою встановлення рівня самочинної інтенсивності $\left(\mathrm{A}_{\mathrm{c}}\right)$ процесів ПОЛ, до 1,5 мл водної витяжки міцелію або 0,5 мЛ КФ (контроль - дистильована вода) додавали розчини трихлороцтової кислоти (ТХО) та тіобарбітурової кислоти (ТБК) до кінцевих концентрацій у реакційній суміші 0,61 та 0,37 моль/дм ${ }^{3}$, відповідно. Суміш кип'ятили на водяній бані протягом 15 хв, після чого швидко охолоджували до $+20^{\circ} \mathrm{C}$. Отриманий розчин центрифугували 15 хв за $1700 \mathrm{~g}$. Із метою визначення рівня індукованої $\left(\mathrm{A}_{\mathrm{i}}\right)$ інтенсивності процесів ПОЛ до вказаних об'ємів водної витяжки міцелію або КФ (контроль дистильована вода) додавали $1 \cdot 10^{-3}$ моль/дм ${ }^{3}$ розчин сірчанокислого заліза і $1 \cdot 10^{-2}$ моль/дм ${ }^{3}$ аскорбінової кислоти. Суміш витримували за $+40{ }^{\circ} \mathrm{C}$ на водяній бані протягом 90 хв. Далі на спектрофотометрі за довжини хвилі 532 і 590 нм вимірювали екстинкцію супернатантів дослідних проб проти контрольних. Самочинну та індуковану інтенсивність ПОЛ міцелію чи КФ 
розраховували за формулою (Chayka et al., 2014; Fedotov, 2016):

$$
A_{c}\left(A_{i}\right)=\frac{\left(\mathrm{E}_{532}-\mathrm{E}_{590}\right) \cdot 10^{6} \cdot V \cdot K}{1,56 \cdot 10^{5} \cdot \mathrm{P}},
$$

де $\mathrm{E}_{532}$ i $\mathrm{E}_{590}$ - показники екстинкції, V - об'єм реакційної суміші (мл), $\mathrm{K}$ - коефіцієнт перерахунку на АСБ міцелію, $10^{6}$ фактор розмірностей, $1,56 \cdot 10^{5}-$ молярний коефіцієнт екстинкції, Р - наважка сирого міцелію (г) або об’єм КФ (мл). Кількість у мікологічному матеріалі продуктів ПОЛ, активних до ТБК (ТБК-АП) виражали у нмоль/г АСБ або нмоль/мл КФ.

За отриманими значеннями $\mathrm{A}_{\mathrm{c}} \mathrm{i} \mathrm{A}_{\mathrm{i}}$ розраховували показник прооксидантної активності (ПОА - характеризує активність прооксидантної складової прооксидантно-антиоксидантної системи) та показник резерву субстратів перекисного окиснення (СПО, який вказує на можливість індукції ПОЛ за дії факторів середовища) за формулами (Chayka et al., 2014; Fedotov, 2016):

$$
\Pi O A=\frac{A_{c}}{A_{i}}, \quad C \Pi O=\frac{A_{i}-A_{c}}{A_{i}} \cdot 100 \% .
$$

На останньому етапі розраховували коефіцієнт рівноваги прооксидантно-антиоксидантної системи (КРПАС) за формулою (Chayka et al., 2014; Fedotov, 2016):

$$
K_{\text {РПAC }}=\frac{A O A}{\Pi O A} .
$$

Культивування штамів проводили у триразовій повторності. Статистичну обробку експериментальних даних проводили з використанням пакета програм для проведення статистичної обробки результатів біологічних експериментів. Різницю між даними вважали достовірною за Р < 0,05 (Prisedskiy, 1999).

\section{Результати}

Прооксидантна активність. Показники прооксидантної активності міцелію (рис. 1) та культурального фільтрату (рис. 2) досліджених штамів мають індивідуальні значення та характеризуються такими ознаками.

ПОА міцелію переважної більшості штамів на 9-ту та 12-ту добу культивування перебуває в межах від 0,15 (штам F-610, 9 ДК) до 0,51 (штам Dq-08, 12 ДК). Виняток - штами P-citr, P-089, P-er та Р-082 роду Pleurotus, активність прооксидантної складової ПАС міцелію на 9-ту добу культивування яких має найвищі значення $0,96 \pm 0,21,0,71 \pm 0,14,0,61 \pm 0,16$ та $0,58 \pm$ 0,23, відповідно. Цікаво відмітити в цій групі штам Р-447, ПОА міцелію якого на 12-ту добу перевищує цей показник на 9-ту добу культивування та дорівнює 0,55 \pm 0,19.
Активність прооксидантної складової прооксидантноантиоксидантної системи в культуральному фільтраті вища за цей показник у міцелії. За найвищими значеннями на 12-ту добу культивування виділяються штами Р-089 $(0,99 \pm 0,17)$ роду Pleurotus i Gl-2 $(0,97 \pm 0,14)$ роду Ganoderma. Далі, в порядку зменшення ПОА КФ ідуть штами F-107, Р-035, 960. Найнижчі значення ПОА КФ зафіксовані на 12-ту добу культивування штаму F-104 $(0,26 \pm 0,19)$ роду Flammulina.

Узагальнюючи отримані експериментальні дані, треба відмітити, що для всіх досліджених штамів базидіоміцетів характерне значне переважання активності прооксидантної складової ПАС у культуральному фільтраті порівняно з цим показником міцелію. Найвищі значення ПОА КФ відмічаються на 12-ту добу культивування штаму Р-089 роду Pleurotus і штаму Gl-2 роду Ganoderma, а міцелію - на 9-ту добу культивування штамів P-citr, P-089, P-er та Р-082 роду Pleurotus. Зареєстровано пряму залежність між показниками ПОА і КФ міцелію кожного штаму, ця залежність та рівень показника не відображають їх систематичного положення.

Резерв субстратів перекисного окиснення. На наступному етапі розраховували резерв субстратів перекисного окиснення (СПО), до яких переважно входять ліпідні сполуки, зокрема поліненасичені жирні кислоти. Його рівень вказує на можливість індукції процесу ПОЛ за дії різних факторів. За рівнем СПО міцелію (рис. 3) досліджені штами умовно поділяються на три групи. До першої належать п'ять штамів (Р-087, Р-082, P-081, Р-12k, Р-192) роду Pleurotus iз низькими значеннями резерву СПО. Тобто для міцелію цих штамів характерна висока інтенсивність процесів ПОЛ із залученням більшості доступних субстратів. До другої групи можна віднести чотири штами (F-112, F-2, F-204, F-vv) роду Flammulina та три штами P-01, P-105, Р-107 роду Pleurotus із помірними значеннями показника резерву СПО. Міцелій цих штамів вирізняється помірною інтенсивністю процесів ПОЛ у застосованих умовах культивування. Переважна більшість (45 штамів) складає третю групу та характеризується високими значеннями показника резерву СПО. Для міцелію цих штамів характерна низька інтенсивність процесів ПОЛ із залученням незначної кількості доступних субстратів та, ймовірно, високим вмістом АО. Найвищі значення резерву СПО міцелію зафіксовані у восьми штамів (Р-447, Р-998, Р-039, P-94, P-2175, P-citr, P-er, D-140) роду Pleurotus та двох штамів (F-107, F-610) роду Flammulina.

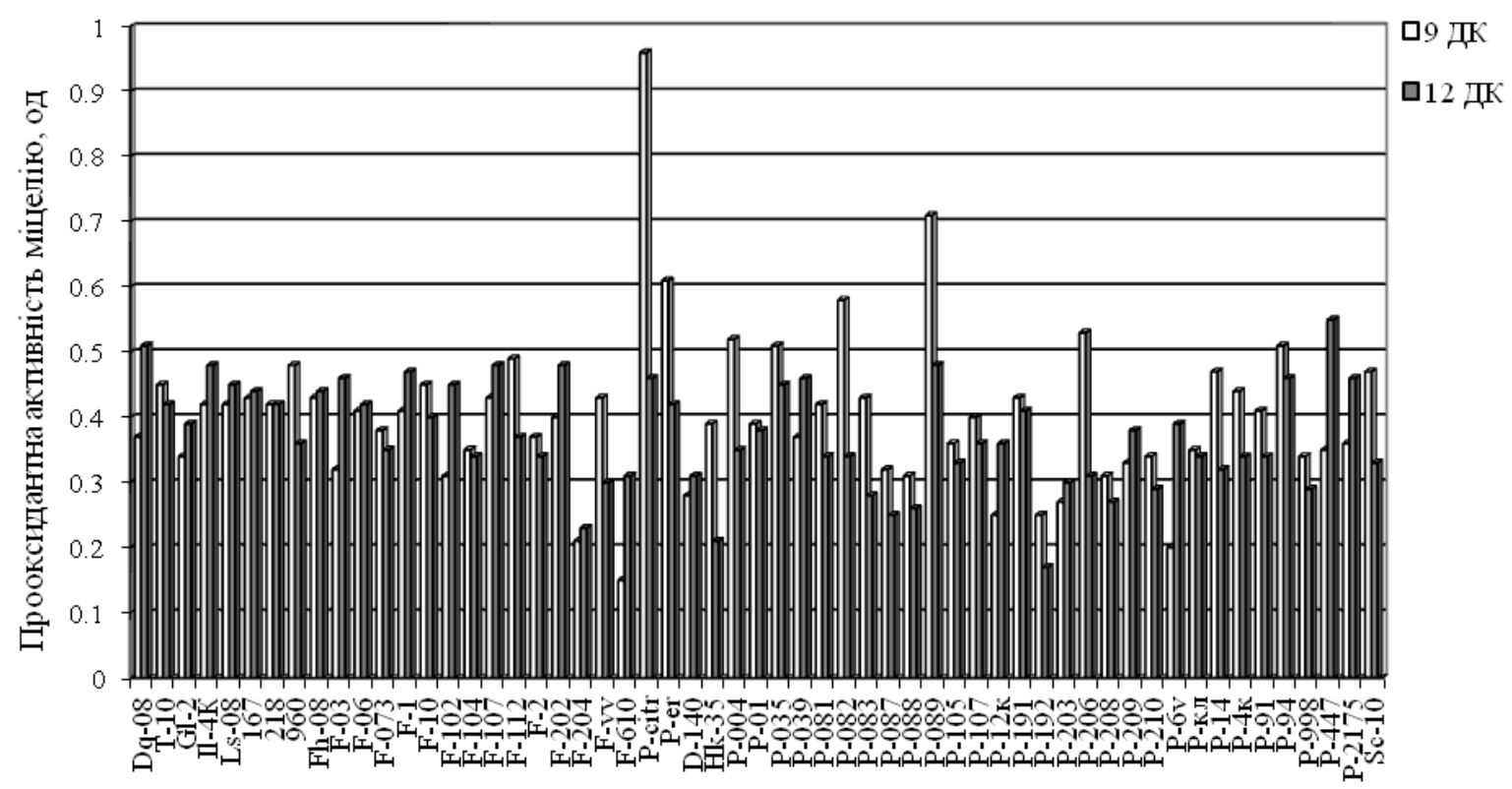

Рис. 1. Прооксидантна активність міцелію штамів на 9-ту (9 ДК) та 12-ту (12 ДК) добу культивування $(\mathrm{n}=3)$ 


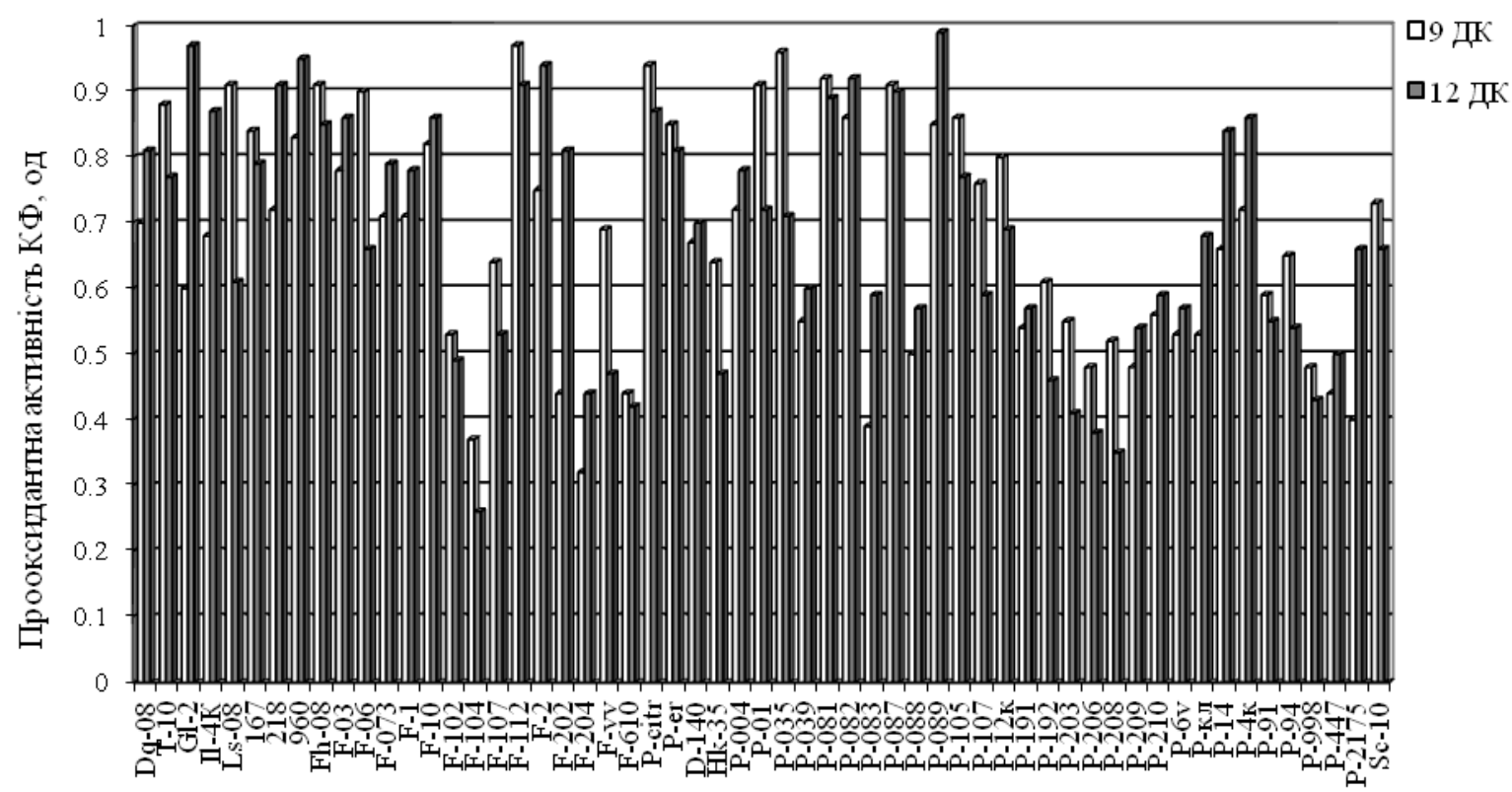

Рис. 2. Прооксидантна активність культурального фільтрату штамів на 9-ту (9 ДК) та 12-ту (12 ДК) добу культивування (n = 3)

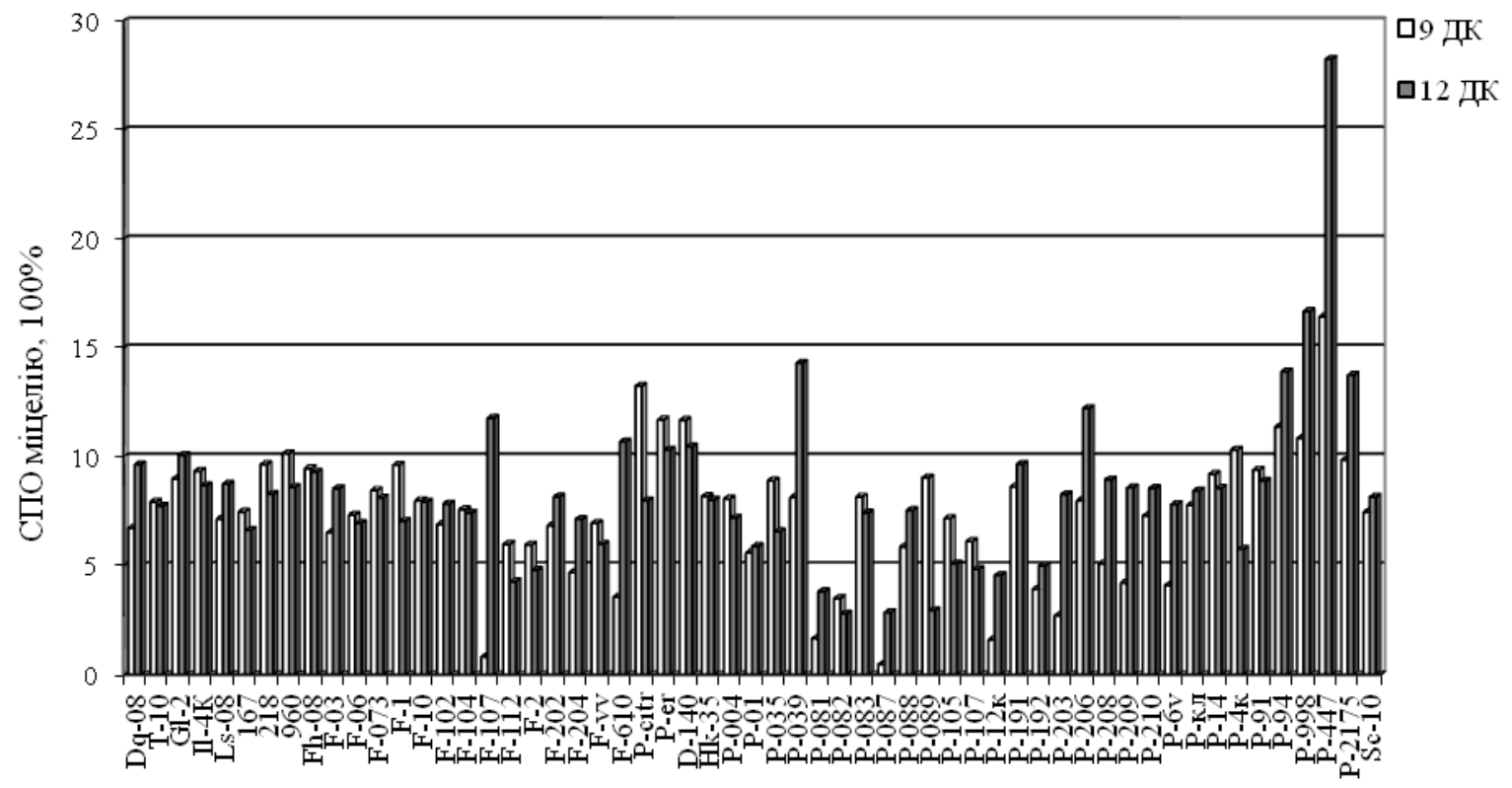

Рис. 3. Показник резерву субстратів перекисного окиснення міцелію штамів на 9-ту (9 ДК) та 12-ту (12 ДК) добу культивування (n=3)

Резерв субстратів перекисного окиснення КФ (рис. 4) значно нижчий за цей показник міцелію. Отримані результати СПО культурального фільтрату можна поділити на дві групи. До першої, зі значеннями показника резерву СПО до 50\%, належать 46 штамів. Найнижчі показники СПО зафіксовано для КФ штамів F-112, P-087, P-082 та P-081. У другу, поліморфну, групу можемо віднести 11 штамів із високими значеннями показника резерву СПО (F-104, F-204, P-208, P-206, P-2175, P-203, F-610, P-998, F-202, F-vv, Hk-35). Для КФ цих штамів властива низька інтенсивність процесів ПОЛ і порівняно висока антиоксидантна активність (АОА).

Підсумовуючи отримані на цьому етапі дані, зазначимо виявлену для переважної більшості штамів суттєву перевагу показників резерву субстратів перекисного окиснення міцелію над таким показником КФ. Найвищі значення резерву СПО міцелію зафіксовані для 8 штамів (Р-447, Р-998, Р-039, Р-94, P-2175, P-citr, P-er, D-140) роду Pleurotus та двох штамів (F-107, F-610) Flammulina. Названі штами перспективні для застосування в індикації певних біотехнологічних процесів чи екологічному тестуванні.
Коефіцієнт рівноваги прооксидантно-антиоксидантної системи. Цей показник відображає співвідношення значень активності антиоксидантної та прооксидантної систем. За переважання останньої (під час посилення неконтрольованих реакцій вільнорадикального окиснення) значення КРПАС мають тенденцію до зниження. У разі зростання активності захисних систем (у тому числі антиоксидантної) показники КРПАС зростають до порівняно високих значень.

Зіставлення коефіцієнтів рівноваги ПАС міцелію та КФ досліджених штамів базидіоміцетів на 9-ту добу культивування (рис. 5) дозволяє поділити їх на три групи. До першої входять п'ять штамів (F-202, F-204, P-083, P-12k, P-206) з однаковими в межах штаму значеннями КРПАС міцелію та КФ. До другої - п'ять штамів роду Pleurotus (P-081, P-082, Р-087, Р-203, Р-209) із вірогідно вищими значеннями КРПАС КФ. Найбільша, третя група, об'єднує 47 штамів із вірогідно вищими значеннями КРПАС 9-добового міцелію. Максимальні значення коефіцієнтів рівноваги ПАС міцелію в цій групі зафіксовані для п'яти штамів: Т-10 (F. fomentarius) та D-140, P-035, P-01 та P-105 (P. ostreatus). Ці штами вирізняються ви- 
соким рівнем АОА міцелію на 9-ту добу культивування та можуть бути рекомендовані як продуценти антиокисних речовин.

Подовження терміну культивування до 12 діб (рис. 6) підтверджує виявлену для переважної білышості штамів тенденцію до переважання значень коефіцієнтів рівноваги ПАС міцелію над такими КФ. Із цієї групи, що складається з 54 штамів, треба відзначити п'ять: Sc-10 (S. commune), Р-кл, Р-14 (P. ostreatus), P-er (P. eryngii) та 960 (A. cylindracea). Названі штами вирізняються найвищими серед зафіксованих значеннями коефіцієнтів рівноваги ПАС 12-добового міцелію. Вони доповнюють групу штамів iз високим рівнем АОА міцелію на 9-ту добу культивування, а також можуть бути рекомендовані як продуценти антиокисних речовин. Треба зауважити, що групи з однаковими та переважаю- чими у КФ значеннями КРПАС на 12-ту добу культивування зменшились до одного штаму F-102 та двох F-1, F-104 (F. velutipes), відповідно. Узагальнюючи результати розрахунків цього етапу досліджень, зазначимо, що для переважної більшості штамів характерне переважання коефіцієнтів рівноваги ПАС міцелію над такими КФ. Максимальні коефіцієнти рівноваги ПАС 9-добового міцелію зафіксовані для штамів Т-10 (F.fomentarius) i D-140, P-035, P-01, P-105 (P. ostreatus), 12-добового - для штамів Sc-10 (S. commune), Р-кл, P-14 (P. ostreatus), P-er (P. eryngii) i 960 (A. cylindracea). Названі штами вирізняються високими значеннями КРПАС і рівнем АОА міцелію на встановлену добу культивування та можуть бути рекомендовані як продуценти антиокисних речовин.

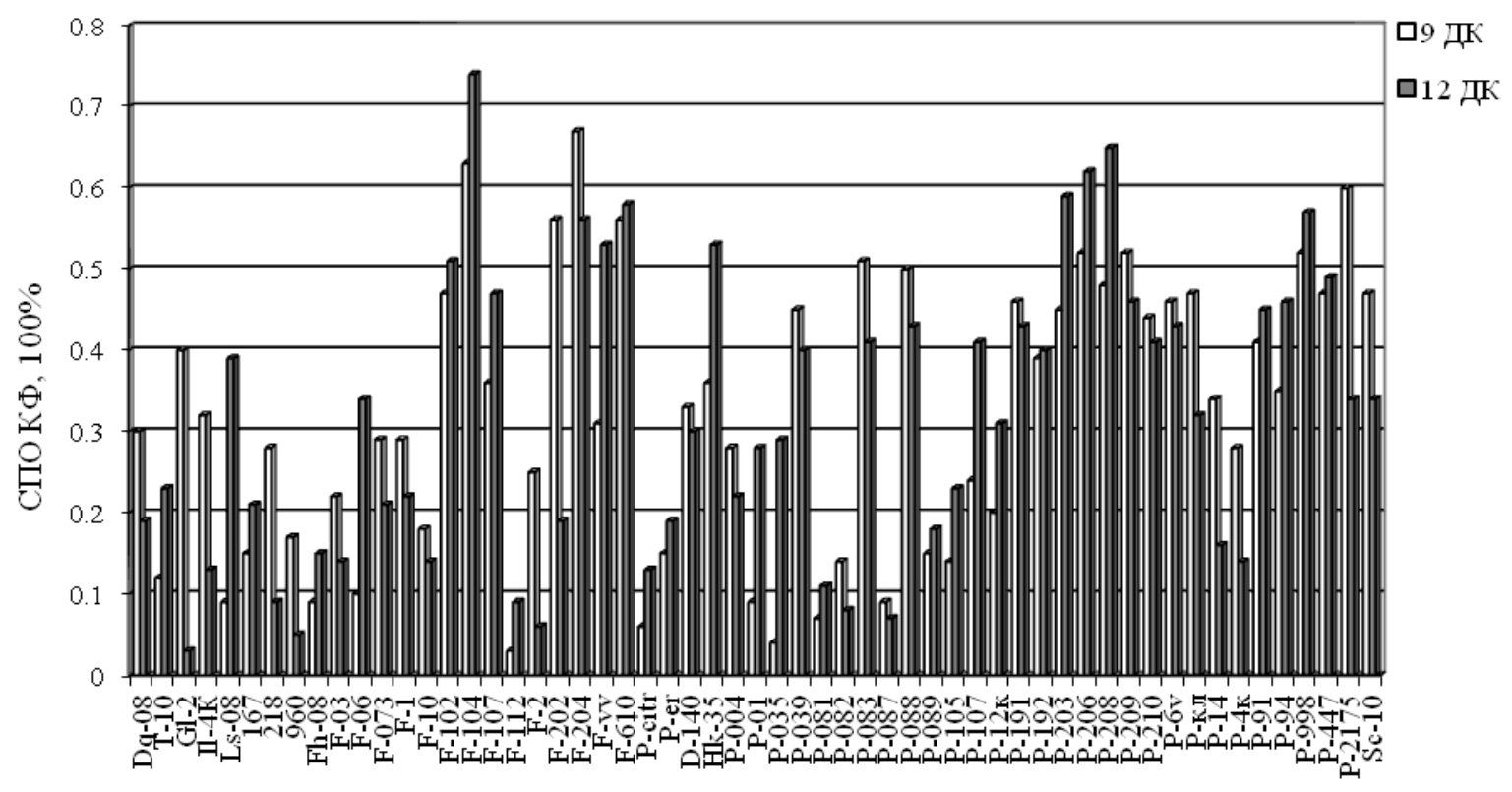

Рис. 4. Показник резерву субстратів перекисного окиснення КФ штамів на 9-ту (9 ДК) та 12-ту (12 ДК) добу культивування (n = 3)

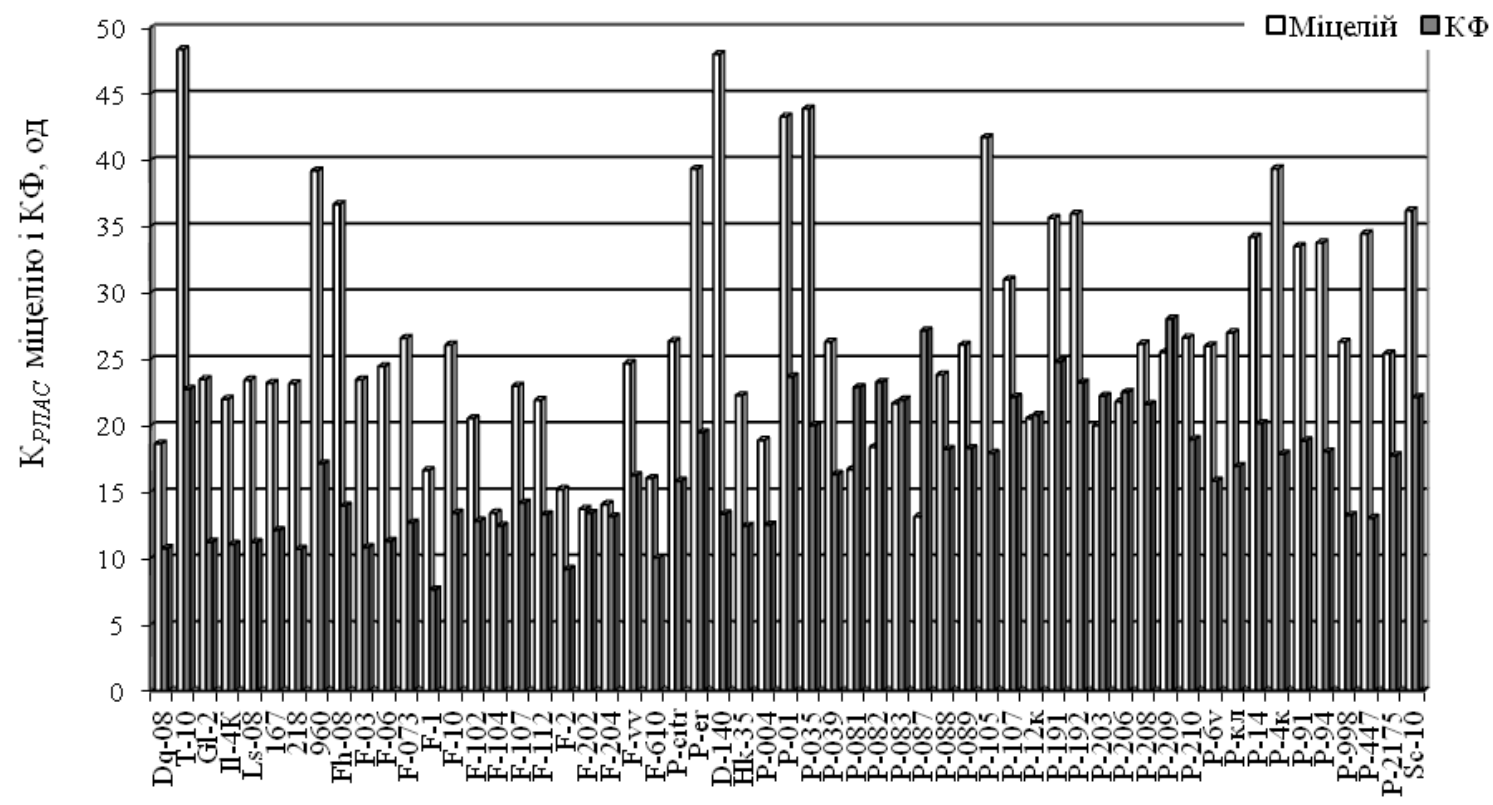

Рис. 5. Коефіцієнт рівноваги прооксидантно-антиоксидантної системи міцелію та КФ штамів на 9-ту добу культивування (n=3)

\section{Обговорення}

У попередніх дослідженнях (Voloshko et al., 2011; Velygodska et al., 2016) установлено динаміку зростання, загальної антиоксидантної активності, рівня самочинної та індукованої інтенсивності процесів перекисного окиснення ліпідів 57 штамів базидіомікотових грибів за їх поверхневого періодичного куль- тивування на глюкозо-пептонному середовищі (Fedotov, 2016). Отримані дані лягли в основу розрахунку та порівняння показників стану прооксидантно-антиоксидантної системи в динаміці росту цих штамів, дозволили виявити певні закономірності реєстрованих показників і з'ясувати перспективи використання досліджених культур. Значне переважання активності прооксидантної складової ПАС у культуральному фільтраті порівняно 3 
цим показником міцелію на 12-ту добу культивування штаму P-089 роду Pleurotus і штаму Gl-2 роду Ganoderma, а міцелію на 9-ту добу культивування штамів P-citr, P-089, P-er та P-082 роду Pleurotus може бути використане під час оцінювання придатності складу живильних середовищ, розроблення способів деструкції хімічно стійких сполук, моніторингу довкілля.

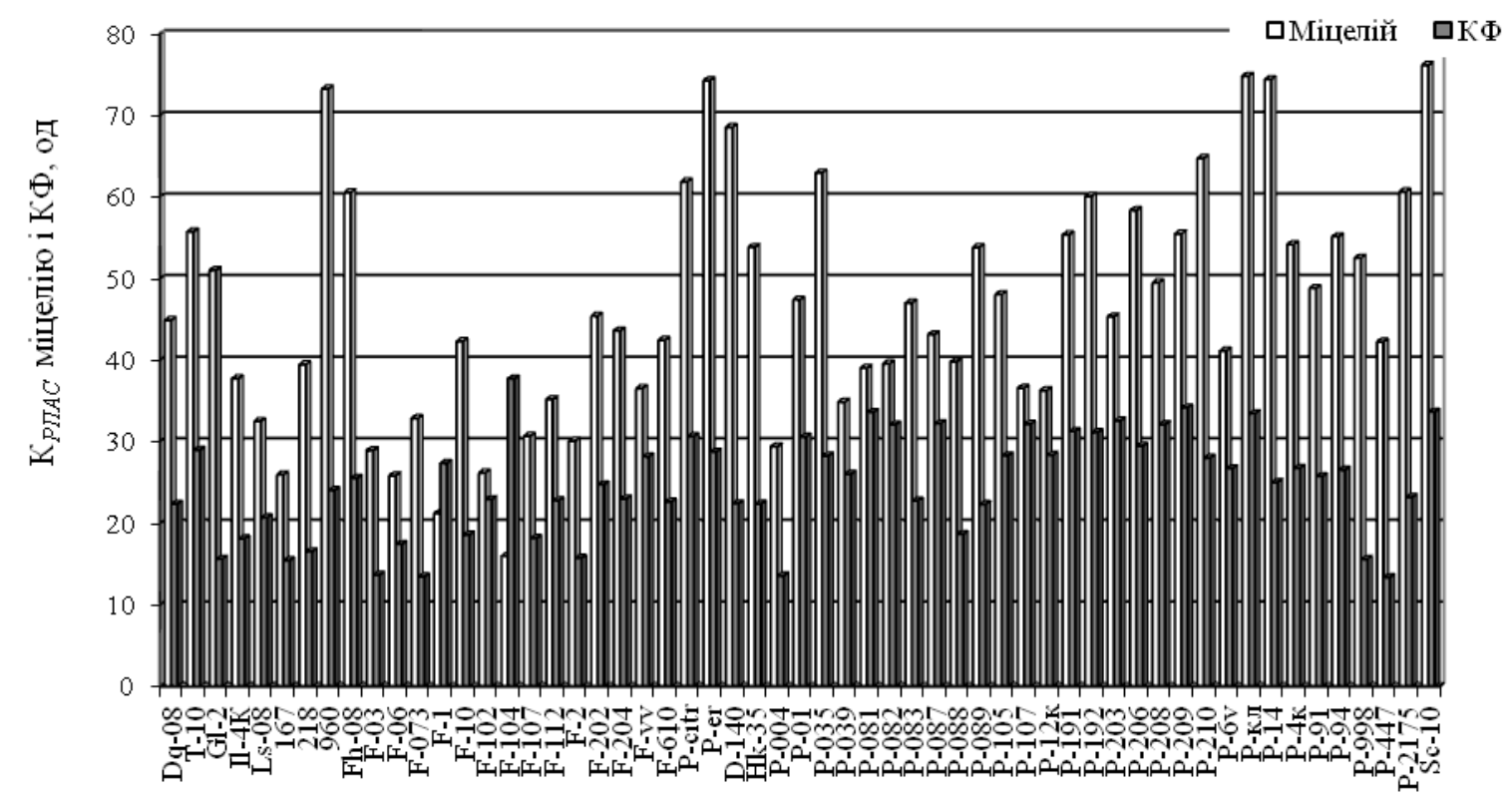

Рис. 6. Коефіцієнт рівноваги прооксидантно-антиоксидантної системи міцелію і КФ штамів на 12-ту добу культивування

Перспективні для застосування в індикації певних біотехнологічних процесів чи екологічному тестуванні штами Р-447, P-998, P-039, P-94, P-2175, P-citr, P-er, D-140 роду Pleurotus та штами F-107, F-610 роду Flammulina, для яких зафіксовані найвищі значення резерву субстратів перекисного окиснення міцелію. На біосинтетичні перспективи використання поодиноких штамів (Gl-2, P-er, P-039, F-610) вказують результати окремих скринінгових досліджень (Voloshko et al., 2011; Chayka et al., 2014; Velygodska et al., 2016).

\section{Висновки}

Для штамів властиве переважання активності прооксидантної складової ПАС у культуральному фільтраті порівняно 3 цим показником міцелію. Найвищі значення прооксидантної активності КФ відмічено на 12 -ту добу культивування штаму P-089 роду Pleurotus і штаму Gl-2 роду Ganoderma, а міцелію на 9-ту добу культивування штамів P-citr, P-089, P-er та P-082 роду Pleurotus. Наявна пряма залежність між показниками ПОА КФ і міцелію кожного штаму. Ця залежність та рівень показника не відображають їх систематичного положення.

Виявлено суттєву перевагу показників резерву субстратів перекисного окиснення міцелію більшості штамів над таким показником КФ. Найвищі значення резерву СПО міцелію зафіксовані для штамів Р-447, P-998, P-039, Р-94, P-2175, P-citr, P-er, D-140 роду Pleurotus та штамів F-107, F-610 роду Flammulina.

Для переважної більшості штамів характерне переважання коефіцієнтів рівноваги ПАС міцелію над такими КФ. Максимальні значення коефіцієнтів рівноваги ПАС 9-добового міцелію зафіксовано для штамів Т-10 ( $F$. fomentarius) i D-140, P-035, P-01, P-105 (P. ostreatus), a 12-добового - для штамів Sc-10 (S. commune), Р-кл, P-14 (P. ostreatus), P-er (P. eryngii) i 960 (A. cylindracea). Названі штами вирізняються високим рівнем АОА міцелію на певну добу культивування та можуть бути рекомендовані як продуценти антиоксидантів грибного походження.

\section{Подяки}

Висловлюємо щиру подяку науковим співробітникам відділу мікології Інституту ботаніки ім. М. Г. Холодного НАН України за співпрацю, надані матеріали Колекції культур шапинкових грибів (IBK), що має статус Національного надбання України.

\section{References}

Al-Maali, G. A., Bisko, N. A., \& Ostapchuk, A. M. (2016). The effect of citrate and sulfate of copper on the biomass composition of the medicinal mushroom Trametes versicolor (Polyporales, Polyporaceae). Visnyk of Dnipropetrovsk University. Biology, Ecology, 24(1), 119-123.

Asatiani, M. D., Elisashvili, V., Songulashvil, G., Reznick, A. Z., \& Wasser, S. P. (2010). Higher basidiomycetes mushrooms as a source of antioxidants. In: M. Rai, G. Kövics (Eds). Progress in Mycology. P. 311-326.

Bitto, A., Sell, C., Crowe, E., Lorenzini, A., Malaguti, M., Hrelia, S., \& Torres, C. (2010). Stress-induced senescence in human and rodent astrocytes. Experimental Cell Research, 316, 2961-2968.

Chang, S. T. (2001). A 40-year journey through bioconversion of lignocellulosic wastes to mushrooms and dietary supplements. International Journal of Medicinal Mushrooms, 3, 299-310.

Chayka, O. V., \& Fedotov, O. V. (2014). Otsinka ekolohichnoho stanu dovkillya z vykorystannyam prooksydantno-antyoksydantnoyi aktyvnosti kul'tur bazydiomitsetiv [The ecology estimation of environment state using prooxidant-antioxidant activity of Basidiomycetes cultures]. Bioresursy $\mathrm{i}$ Pryrodokorystuvannya, 6, 5-11 (in Ukrainian).

Cherubini, A., Ruggiero, C., Morand, C., Lattanzio, F., Dell'aquila, G., Zuliani, G., Di Iorio, A., \& Andres-Lacueva, C. (2008). Dietary antioxidants as potential pharmacological agents for ischemic stroke. Current Medicinal Chemistry, 15, 1236-1248.

Droge, W. (2002). Free radicals in the physiological control of cell function. Physiological Reviews, 82, 47-95.

Dudka, Y. A., Wasser, S. P., \& Ellanskaya, Y. A. (2003). Metody eksperimental'noy mikologii [Methods of experimental mycology]. Naukova Dumka, Kyiv (in Russian)

Egorova, A. S., Gessler, N. N., Ryazanova, L. P., Kulakovskaya, T. V., \& Belozerskaya, T. A. (2015). Stress resistance mechanisms in the indicator fungi from highly radioactive Chernobyl Zone sites. Mikrobiologiia, 84(2), 152-158.

Eriksson, K. E. L., Blanchette, R. A., \& Ander, P. (1990). Microbial and enzymatic degradation of wood and wood components. Springer-Verlag, Berlin.

Fedotov, O. V. (2016). The lipid peroxidation intensity of fungi strains from the orders Agaricales and Polyporales. Visnyk of Dnipropetrovsk University. Biology, Ecology, 24(2), 317-323.

Fedotov, O. V. (2016). Total antioxidant activity of some Basidiomycetes strains in growth dynamic. Biological Bulletin of Bogdan Chmelnitskiy Melitopol State Pedagogical University, 6(2), 158-165.

Fedotov, O. V., Chayka, O. V., Voloshko, T. E., \& Velyhods'ka, A. K. (2012). Kolektsiya kul'tur shapynkovykh hrybiv - osnova mikolohichnykh doslidzhen' ta stratehiyi zberezhennya bioriznomanittya bazydiomitsetiv 
Culture Collection of mushrooms - the basis of mycological research and biodiversity conservation strategies Basidiomycetes]. Visnyk Donets'koho Universytetu, 1, 209-213 (in Ukrainian).

Fruehauf, J. P., \& Meyskens, F. L. (2007). Reactive oxygen species: A breath of life or death? Clinical Cancer Research, 13(1), 789-794.

Halliwell, B. (2006). Reactive species and antioxidants. Redox biology is a fundamental theme of aerobic life. Plant Physiology, 141, 312-322.

Kapich, A. N. (2010). Oxidizability of unsaturated fatty acids and of a nonphenolic lignin structure in the manganese peroxidase-dependent lipid peroxidation system. Enzyme and Microbial Technology, 46(2), 136-140.

Kirk, P. M., Cannon, P. F., Minter, D. W., \& Stalpers, J. A. (2008). Dictionary of the fungi. CABI, Wallingford.

Leonowicz, A., Matuszewska, A., \& Luterek, J. (1999). Biodegradation of lignin by white rot fungi. Fungal Genetics and Biology, 27, 175-185.

Pham-Huy, L. A., He, H., \& Pham-Huyc, C. (2008). Free radicals, antioxidants in disease and health. International Journal of Biomedical Science, 4, 89-96.

Prisedskiy, Y. G. (1999). Statystychna obrobka rezul'tativ biolohichnykh eksperymentiv [Statistical processing of biological experiments results]. Kassiopeya, Donetsk (in Ukrainian).
Syrchin, S. A., \& Grodzinskaya, A. A. (2015). Evaluation of antioxidant activity of some wild macromycetes. Ukrainian Botanical Journal, 72(3), 257-260 (in Ukrainian).

Velygodska, A. K., \& Fedotov, O. V. (2016). The production and analysis of carotenoid preparations from some strains of xylotrophic Basidiomycetes. Visnyk of Dnipropetrovsk University. Biology, Ecology, 24(2), 290-294.

Voloshko, T. E., \& Fedotov, O. V. (2011). Skryninh shtamiv bazydiomitsetiv za aktyvnistyu antyoksydantnykh oksydoreduktaz [Screening of basidiomycetes strains on the antioxidant activity of oxidoreductases]. Microbiology and Biotechnology, 16, 69-81 (in Ukrainian).

Wasser, S. P. (2010). Medicinal mushroom science: History, current status, future trends, and unsolved problems. International Journal of Medicinal Mushrooms, 12(1), 1-16.

Wasser, S. P. (2011). Current findings, future trends, and unsolved problems in studies of medicinal mushrooms. Applied Microbiology and Biotechnology, 89, 1323-1332.

Winquist, E., Moilanen, U., \& Mettala, A. (2008). Production of lignin modifying enzymes on industrial waste material by solid-state cultivation of fungi. Biochemical Engineering Journal, 42, 128-132. 